\title{
OPTIMISATION DESIGN AND TECHNOLOGICAL PARAMETERS OF CLOVER THRESHER K-0.3
}

\author{
Maksim Simonov $^{1}$, Aleksandr Burkov², Valentin Mokiyev ${ }^{2}$ \\ ${ }^{1}$ Vyatka State University, Russia; \\ ${ }^{2}$ Federal Agricultural Research Center of the North-East named N.V. Rudnitskogo, Russia \\ simaksim@mail.ru,burkov.46@mail.ru,dizel154@bk.ru
}

\begin{abstract}
In the course of the research of the operational procedure of the clover thresher K- 0.3 at alfalfa (Medicago) seed threshing the authors set a purpose of studying the influence of the machine design and technological parameters on the indicators of the quality of the industrial process of alfalfa seed threshing. To achieve the purpose, the authors adopted and implemented a Box-Behnken statistical design. After the plan implementation and processing of the experiment results the models of regression analysis of the second order were obtained for the extent of seed threshing and crushing. As a result, the authors draw a conclusion that a significant influence on the change of the seed threshing extent is provided by the change in the drum rotation frequency. The feed of the original material and the gap between the rasps and the threshing surface has a smaller impact on the change in the extent of alfalfa. The change of the seed threshing value is largely influenced by all of these three factors. The most significant of them is the drum rotation frequency. Based on the requirements set to the values of the quality indicators for the industrial process of grass seed threshing (the extent $\varepsilon$ of seed threshing is not less than $97 \ldots 98 \%$, crushing of $d$ seeds not more than $1.5 \%$ ) the authors found an intermediate solution in relation to combination of the factor levels: $q=50 \ldots 350 \mathrm{~kg} \cdot \mathrm{h}^{-1}$; $\delta=\delta_{\text {in }}=\delta_{\text {out }}=3 \ldots 5 \mathrm{~mm} ; n=1300 \ldots 1400 \mathrm{~min}^{-1}$. To evaluate the validity of the research outcomes the authors conducted an experiment at registering the factor levels in relation to the assumed optimal values: $n=1400 \mathrm{~min}^{-1}, q=350 \mathrm{~kg} \cdot \mathrm{h}^{-1}$; and $\delta=3 \mathrm{~mm}$. As a result, the authors obtained the values of the seed threshing extent $\varepsilon=96.1 \%$ against $\varepsilon=96.4 \%$, and crushing $d=0.68 \%$ against $d=0.70 \%$, which, with a probability of $95 \%$, confirms the validity of the model and the results of the conducted research.
\end{abstract}

Keywords: alfalfa, thresher, grass, seeds, parameters, optimisation.

\section{Introduction}

The stable development of the agrarian sector of animal breeding is reached due to the existence of a sound nutritive base, the main source of which is provided by perennial grasses [1;2].

Alfalfa is a highly-nourishing perennial pod-bearing grass rich in plant protein and balanced in terms of its amino acid content, containing a large amount of carotene, calcium and other important elements of agricultural animals' feeding. That is why the feeding plant alfalfa has been used for thousands of years and gained a wide application at many world continents [3-6].

For the last decades the gross seed manufacture has reduced 3-4 times comparing with the end of the 80 -s of the 20th century, while certified seeds comprise approximately $40 \%$ of their gross collection [7], although an efficient feed production cannot exist without a wide range of high-quality medium-priced plant seeds. That is why development of new technologies and equipment is one of the top priority scientific tasks to improve the seed farming efficiency [1], the quality of the industrial process implementation, machine performance at post-harvest processing of plant seeds.

The seed threshing process for perennial grasses is quite a specific procedure and requires the application of special clover threshers [8;9]. The application of such special machines in the technology of plant seed post-harvest processing allows 2-5 times reduction of the seed losses and decrease in their dam-aging by $20 . . .30 \%$ [10-16].

\section{Materials and methods}

In this connection FARC North-East developed the clover thresher K-0.3B (Fig. 1) [17] intended for threshing clover, alfalfa and other legume grass seeds, installation into flow production lines for post-harvest processing of perennial grasses. This device is of an axial-rotor type $[3 ; 18]$, and its specific feature is simplicity of the design, small dimensions and low power consumption.

The clover thresher operates as follows. Using a loading mechanism of the production line (conveyor, bucket elevator, etc.), the treated material is fed into the loading mouth 1 , after that it passes into the operation area, consisting of the rotating drum 2 and deck 4 . At the drum 2 rotation rasps 5 pull the thrashed heap along the deck 4 and due to the ledges, located angle-wise towards the 
rasp long axis, ensure its axial movement. Further, the thrashed heap is threshed because of normal pressure in the compressed material layer and the friction force. Threshed seeds and small admixtures are fed from the operation area through the deck gaps 9, while the remaining threshed materials through the discharge opening of the body 10 into the receiver of the threshed material 11 and are further let out. The threshed material from the receiver 11 is led into a further machine in the technological cycle.

a)

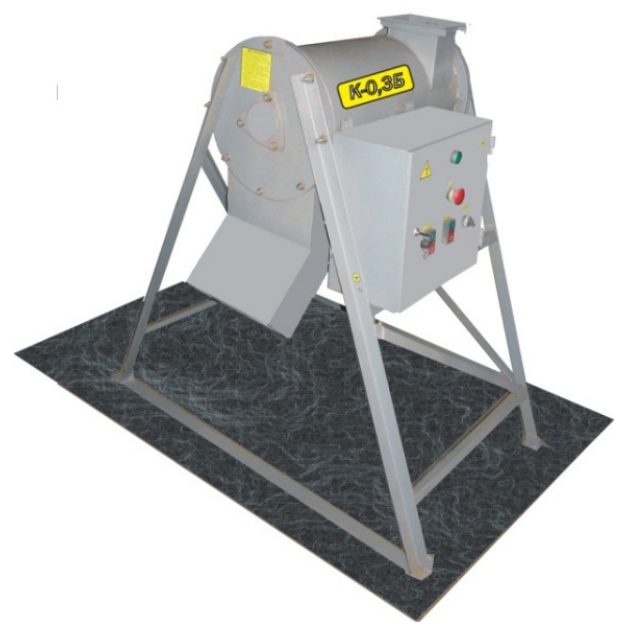

b)

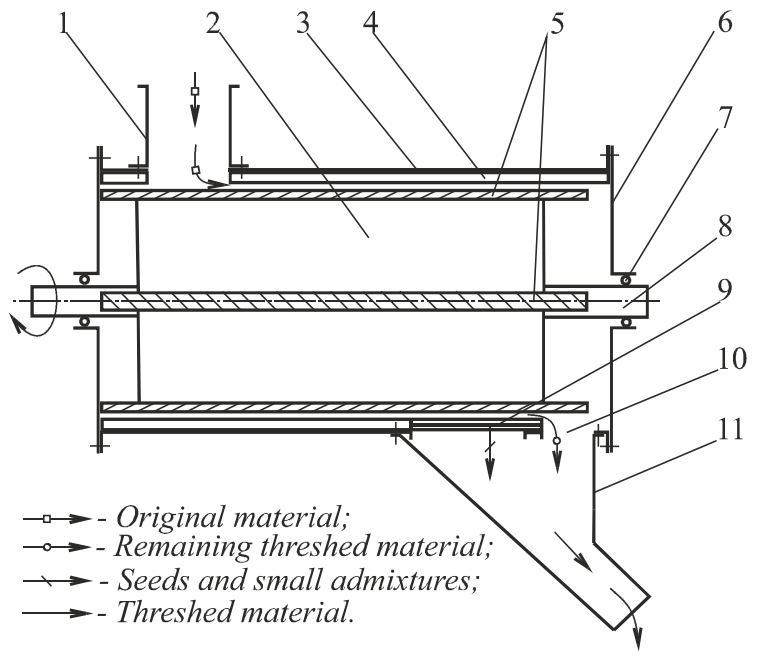

Fig. 1. General view (a) and process flow diagram of clover thresher K-0.3B (b): 1 - loading mouth; 2 - drum; 3 - body; 4 - deck; 5 - rasps; 6 - flange; 7 - bearing; 8 - shaft; 9 - deck gaps; 10 - discharge opening; 11 - ground material receiver

To study the influence of the machine parameters on the quality indicators of the industrial process of alfalfa seed threshing the authors adopted and implemented the Box-Behnken design of the second order for three factors [19].

The factors, intervals and levels of their variation (Table 1) were selected by the method of priori ranging on the basis of the previous research results $[3 ; 20]$.

Factors, registering levels and variation intervals

Table 1

\begin{tabular}{|c|c|c|c|c|c|}
\hline \multirow{2}{*}{$\begin{array}{c}\text { Coded } \\
\text { factor } \\
\text { designatio } \\
n\end{array}$} & \multirow{2}{*}{$\begin{array}{c}\text { Name of factors, their designation } \\
\text { and measurement unit }\end{array}$} & \multicolumn{3}{|c|}{ Levels of factors } & \multirow{2}{*}{$\begin{array}{l}\text { Variation } \\
\text { intervals }\end{array}$} \\
\hline & & -1 & $\mathbf{0}$ & +1 & \\
\hline$x_{1}$ & Feeding of $q$ original material, $\mathrm{kg} \cdot \mathrm{h}^{-1}$ & 50 & 150 & 350 & 150 \\
\hline$x_{2}$ & Drum rotation $n$ frequency, $\min ^{-1}$ & 1100 & 1300 & 1500 & 200 \\
\hline$x_{3}$ & $\begin{array}{c}\text { Gap } \delta \text { between the rasps and the } \\
\text { threshing surface, } \mathrm{mm}\end{array}$ & 3 & 5 & 7 & 2 \\
\hline
\end{tabular}

The experiments were conducted at the number of rasps $Z=4$. Alfalfa hull with the humidity $7 \ldots 10 \%$ was an original material at the conduct of tests of the experiment plan. The adequacy hypothesis was tested using the Fisher's F-test. Regression models were evaluated for adequacy to the real process with probability $P=0.95$.

\section{Results and discussion}

After the plan implementation and processing of the experiment results the models of regression analysis of the second order were obtained for the extent of seed threshing and crushing, \%:

$$
\begin{aligned}
& \varepsilon=95.45-0.80 \cdot x_{1}+1.36 \cdot x_{2}-0.59 \cdot x_{3}-0.10 \cdot x_{1}^{2}+0.24 \cdot x_{1} \cdot x_{2}- \\
& -0.44 \cdot x_{1} \cdot x_{3}-0.17 \cdot x_{2}^{2}-0.07 \cdot x_{2} \cdot x_{3}+0.09 \cdot x_{3}^{2}, \%
\end{aligned}
$$




$$
\begin{aligned}
& d=0.39-0.28 \cdot x_{1}+0.54 \cdot x_{2}-0.222 \cdot x_{3}+0.10 \cdot x_{1}^{2}-0.18 \cdot x_{1} \cdot x_{2}+0.08 \cdot x_{1} \cdot x_{3}+ \\
& +0.21 \cdot x_{2}^{2}-0,18 \cdot x_{2} \cdot x_{3}+0.03 \cdot x_{3}^{2}, \%(2)
\end{aligned}
$$

After excluding insignificant factors from the regression models (1) and (2) and recalculation of the remaining factors the models will be formulated as follows, $\%$ :

$$
\begin{gathered}
\varepsilon=95.36-0.80 \cdot x_{1}+1.36 \cdot x_{2}-0.59 \cdot x_{3}+0.24 \cdot x_{1} \cdot x_{2}-0.44 \cdot x_{1} \cdot x_{3}, \% \\
d=0.41-0.28 \cdot x_{1}+0.54 \cdot x_{2}-0.22 \cdot x_{3}+0.10 \cdot x_{1}{ }^{2}-0.18 \cdot x_{1} \cdot x_{2}+0.08 \cdot x_{1} \cdot x_{3}+0.21 \cdot x_{2}{ }^{2}-0.18 \cdot x_{2} \cdot x_{3}, \% .
\end{gathered}
$$

The analysis of regression models (3) and (4) was conducted with the help of two-dimensional sections of the response surfaces (Fig. 2).

The maximum value of the threshing extent $\varepsilon=97.4 \%$ is reached at the experiment area border: $x_{1}=-1\left(q=50 \mathrm{~kg} \cdot \mathrm{h}^{-1}\right) ; x_{2}=1\left(n=1500 \mathrm{~min}^{-1}\right) ; x_{3}=-1(\delta=3 \mathrm{~mm})$.

The minimal crushing value $d=0.03 \%$ of seeds is reached at: $x_{1}=0.4\left(q=260 \mathrm{~kg} \cdot \mathrm{h}^{-1}\right) ; x_{2}=-0.7$ $\left(n=1160 \mathrm{~min}^{-1}\right) ; x_{3}=1(\delta=7 \mathrm{~mm})$.

A significant influence on the change of the seed threshing extent $\varepsilon$ is provided by the change in the drum rotation frequency $n$. For instance, at $\delta=3 \mathrm{~mm}$ and $q=50 \mathrm{~kg} \cdot \mathrm{h}^{-1}$ the increase of $n$ from 1100 up to $1500 \mathrm{~min}^{-1}$ leads to the increase of $\varepsilon$ from 95.2 up to $97.4 \%$, while at $q=350 \mathrm{~kg} \cdot \mathrm{h}^{-1}$ from 94.0 up to $97.2 \%$.

The two remaining factors have less influence onto the change of the values of the alfalfa seed threshing extent $\varepsilon$. For instance, the decrease in $\delta$ from 7 to $3 \mathrm{~mm}$ at $q=50 \mathrm{~kg} \cdot \mathrm{h}^{-1}$ and $n=1500 \mathrm{~min}^{-1}$ leads to the increase in the value $\varepsilon$ only by $0.3 \%$ (from 97.1 to $97.4 \%$ ), while the increase in the feed $q$ of the original material into the threshing device from 50 to $350 \mathrm{~kg} \cdot \mathrm{h}^{-1}$ at $\delta=3 \mathrm{~mm}$ and $n=1500 \mathrm{~min}^{-1}$ results in the increase of $\varepsilon$ only by $0.2 \%$ (from 97.2 to $97.4 \%$ ).

The change of the seed threshing value $d$ is largely influenced by all of these three factors. The most significant of them is the drum rotation frequency $n$. Thus, at $\delta=3 \mathrm{~mm}$ and $q=50 \mathrm{~kg} \cdot \mathrm{h}^{-1}$ the increase of $n$ from 1100 up to $1500 \mathrm{~min}^{-1}$ leads to the increase of $d$ from 0.38 up to $2.19 \%$ (by $1.81 \%$ ), while at $q=350 \mathrm{~kg} \cdot \mathrm{h}^{-1}-$ by $1.08 \%$ (from 0.04 up to $1.12 \%$ ).

The gap change has lower influence on the $d$ values. For example, at $q=350 \mathrm{~kg} \cdot \mathrm{h}^{-1}$ and $n=1500 \mathrm{~min}^{-1}$ the decrease in $\delta$ from 7 to $3 \mathrm{~mm}$ leads to a quite natural increase in $d$ from 0.47 to $1.12 \%$ (by $0.65 \%$ ).

The least influence on the value of seed crushing $d$ is provided by the change in the feed $q$ of the original material. Thus, for instance, at $n=1100 \mathrm{~min}^{-1}$ and $\delta=3 \mathrm{~mm}$ the increase of the $q$ feed from 50 to $350 \mathrm{~kg} \cdot \mathrm{h}^{-1}$ leads to the decrease of $d$ from 0.38 to $0.04 \%$ (by $0.34 \%$ ).

The cause and effect relations between the regularities of the quality indicator change of the industrial process of alfalfa seed threshing are the same as the previously obtained interconnections between the parameter influence and the clover seed threshing quality indicators [3].

The described regularities in terms of the influence the studied factors have on the quality indicators of the alfalfa seed threshing are preserved for the total planning area. The optimal area for the response of the extent $\varepsilon$ of seed threshing (maximum value of response function) and their crushing $d$ (minimum response function value) is located in various spots of a factor space. The extent $\varepsilon$ of seed threshing takes its maximum value $\varepsilon_{\max }=97.4 \%$ on the border of a two-factor space at the following combination of the studied factors: $x_{1}=-1\left(q=50 \mathrm{~kg} \cdot \mathrm{h}^{-1}\right) ; x_{2}=1\left(n=1500 \mathrm{~min}^{-1}\right) ; x_{3}=-1$ $(\delta=3 \mathrm{~mm})$.

The seed crushing $d$ takes its minimum value $(d=0.03 \%)$ at $x_{1}=0.4\left(q=260 \mathrm{~kg} \cdot \mathrm{h}^{-1}\right) ; x_{2}=-0.7$ $\left(n=1160 \mathrm{~min}^{-1}\right) ; x_{3}=1(\delta=7 \mathrm{~mm})$.

Based on the requirements set to the values of the quality indicators for the industrial process of grass seed threshing (the extent $\varepsilon$ of seed threshing is not less than $97 \ldots 98 \%$, crushing $d$ seeds - not more than $1.5 \%$ ) the authors found an intermediate solution in relation to the combination of the factor levels: $q=50 \ldots 350 \mathrm{~kg} \cdot \mathrm{h}^{-1} ; \delta=\delta_{\text {in }}=\delta_{\text {out }}=3 \ldots . .5 \mathrm{~mm} ; n=1300 \ldots 1400 \mathrm{~min}^{-1}$. 

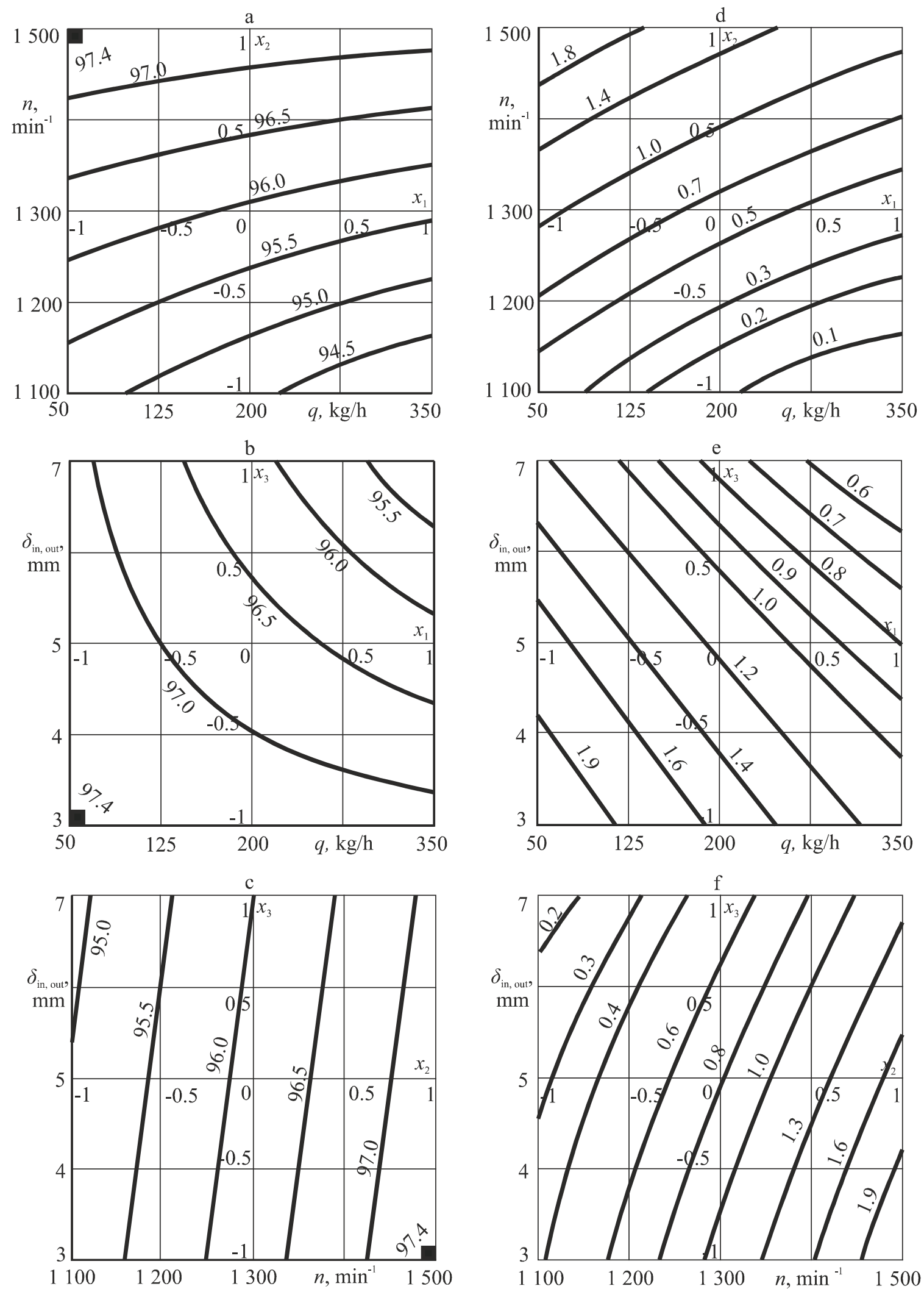

Fig. 2. Two-dimensional sections of response surfaces for threshing $\varepsilon$ of alfalfa seeds and of $\boldsymbol{d}$ seeds: $\mathrm{a}$ - at $x_{3}=-1(\delta=3 \mathrm{~mm}) ; \mathrm{b}-$ at $x_{2}=1\left(n=1.500 \mathrm{~min}^{-1}\right) ; \mathrm{c}-$ at $x_{1}=-1\left(q=50 \mathrm{~kg} \cdot \mathrm{h}^{-1}\right)$;

$$
\mathrm{d}-\text { at } x_{3}=-1(\delta=3 \mathrm{~mm}) ; \mathrm{e}-\text { at } x_{2}=1\left(n=1.500 \mathrm{~min}^{-1}\right) ; \mathrm{f}-\text { at } x_{1}=-1\left(q=50 \mathrm{~kg} \cdot \mathrm{h}^{-1}\right)
$$

To evaluate the validity of the research outcomes the authors conducted an experiment at registering the factor levels in relation to the assumed optimal values: $n=1400 \mathrm{~min}^{-1}, q=350 \mathrm{~kg} \cdot \mathrm{h}^{-1}$; and $\delta=3 \mathrm{~mm}$. As a result, the authors obtained the values of the seed threshing extent $\varepsilon=96.1 \%$ 
against $\varepsilon=96.4 \%$ using the regression analysis model (3) and crushing $d=0.68 \%$ against $d=0.70 \%$ using the regression analysis model (4), which, with a probability of $95 \%$, confirms the validity of the model and results of the conducted research.

\section{Conclusions}

In the course of the experimental research the authors obtained the design and technological parameters of the clover thresher $\mathrm{K}-0.3$ at alfalfa seed threshing: $q=50 \ldots 350 \mathrm{~kg} \cdot \mathrm{h}^{-1}$; $\delta=\delta_{\text {in }}=\delta_{\text {out }}=3 \ldots 5 \mathrm{~mm} ; n=1300 \ldots 1400 \mathrm{~min}^{-1}$.

\section{References}

[1] Шуплецова С.Н. Организация семеноводства многолетних трав Кировской области (Organization of seed farming of perennial grasses of Kirov region). Relevant issues of economic science: strategy of implementation of National projects: Collection of scientific papers. Kirov, pp. 229-232. (In Russian).

[2] Рыбалкин П.Н., Волошин М.И. Состояние и перспективы селекционносеменоводческих работ с кормовыми культурами в КНИИСХ (State and prospects of selection seed-growing works with feed crops in Krasnodar Agricultural Research Institute). Collection of scientific papers of Krasnodar Agricultural Research Institute. Krasnodar, 2001, pp. 3-7. (In Russian).

[3] Бурков А.И., Симонов М.В., Корякин В.А. Использование аксиально-роторного вытирающего устройства для вытирания семян клевера (Use of axial\&rotor thresher for clover seed threshing). Reports of the Russian Academy of agricultural sciences, 2009, No 5, pp. 58-61. (In Russian).

[4] Тарковский М.И. Люцерна (Alfalfa). Moscow: Kolos, 1974. 240 p. (In Russian).

[5] Гончаров П.А., Лубенец П.А. Биологические аспекты возделывания Люцерны (Biological aspects of Alfalfa cultivating). Novosibirsk: Nauka. 1985. 255 p. (In Russian).

[6] Буркашева М.А. Вопросы селекции и семеноводства люцерны (Alfalfa selection and seed farming issues). Tashkent: Publishing House "Fan", 1977. 120 p. (In Russian).

[7] Федоренко В. Ф. Уборка и послеуборочная обработка семян трав (Harvest and post-harvest grass seed processing). Moscow: FSSI "Rosinformagrotekh", 2003. 268 p. (In Russian).

[8] Федосеев Б.В. Механизация процессов уборки семенников многолетних трав и очистка семян (Mechanization of perennial grass seed plants and seed cleaning). Moscow: Publishing house of the Ministry of Agriculture and Procurement of the USSR, 1980. 56 p. (In Russian).

[9] Селекция и семеноводство многолетних трав (Seed selection and farming of perennial grasses). Moscow: Kolos, 1978. 304 p. (In Russian).

[10] Киселев Н.П., Кормщиков А.Д., Рублев В.И. и др. Уборка семенников клевера. Технологии и технические средства (Clover seed plant harvest. Technologies and technical means). Kirov: Agricultural Research Institute of North-East, 1989. 32 p. (In Russian).

[11]Тарасенко А.П., Солнцев В.Н., Шатохин И.В. Обработка невеяного вороха (Processing of not winnowed thrashed heap). Rural mechanic, 2001, No 7, pp. 23-24. (In Russian).

[12] Шаршунов В.А., Ракуть Н.Н. Уборка белого клевера на семена (Dutch clover harvest for seeds). Rural mechanic, 1999, No 7, pp.10-11. (In Russian).

[13] Palenski-Brown F.J. Effects of presowing treatments on germination of Medicago ruthenica (L.) Trautv. A.C.P. Chu. - Lebed. syn. Trigonella ruthenica L., N. Z. J. agr. Res, vol.32, 1989, 443 p.

[14]Канарев Ф.М., Вербицкая Л.П., Ульянов В.С. Уборка семян люцерны с обмолотом на стационаре (Cleaning alfalfa seed with thresh at the stationary point). Saint-Petersburg, 1992. 19 p. (In Russian). Agriculture, 1987, No 7, pp.15-16. (In Russian).

[15]Луцкин В.Н. Обоснование уборки семенников трав с обмолотом на стационаре (Justification of harvesting of grass testes with threshing at a stationary point). Engineering support of mechanized processes in crop production. Chelyabinsk, 1990 pp. 39-43. (In Russian).

[16]Волошин М.И., Куцеев В.В. Совершенствование технологического процесса уборки люцерны на семена (Improvement of the technological process of harvesting alfalfa seeds). Collection of scientific works of the Adygeya scientific research Institute of agriculture. Maikop, vol. 4, 1982, pp. 273-275. (In Russian). 
[17]Бурков А.И., Симонов М.В., Корякин В.А. Клеверотерка для фермера (Clover thresher for farmer). Rural mechanic, 2007, No 12, pp.14-49. (In Russian).

[18]Бурков А.И., Симонов М.В., Корякин В.А. Вытирающее устройство (Threshing device). Patent of the Russian Federation No 2316170, 2008. (In Russian).

[19] Анисимов Н.П. Об использовании методики планирования эксперимента в соответствие с трехуровневыми планами Бокса-Бенкена (On use of method of experiment planning in compliance with three-level Box-Behnken designs). Bulletin of Master's studies, 2017, No 2-2 (65), pp.32-36. (In Russian).

[20]Бурков А.И., Симонов М.В. Исследование рабочего процесса клеверотерки К-0.3 при домолоте семенников райграса (Research of operational process of clover thresher K-0.3 at finish grinding of Ryegrass seed-bearing plants). Agricultural science of European North-East, 2010, No 1, pp. 68-71. (In Russian). 